\title{
Biosurfactants Production Ability of Lactic Acid Bacteria Strains, Emulsification Activity and Cell Adhesion to Hydrocarbons
}

\author{
ADRIAN MATEI ${ }^{1}$, SORIN MATEI $^{2 *}$, GABI-MIRELA MATEI ${ }^{2}$, CĂLINA PETRUȚA CORNEA $^{3}$ \\ ${ }^{1}$ Oncology Institute "Prof. dr. Alexandru Trestioreanu", 252 Fundeni Av., 022328, Bucharest, Romania \\ ${ }^{2}$ National Research and Development Institute for Soil Science, Agrochemistry and Environment, 61 Marasti Blvd., \\ 011464, Bucharest, Romania \\ ${ }^{3}$ UASVM Bucharest, Faculty of Biotechnology, 59 Marasti Blvd., 011464, Bucharest, Romania
}

\begin{abstract}
The paper presents the results of research carried out for screening of 10 lactic acid bacteria strains with antifungal activity for their ability to produce biosurfactants and to select the most performant strains for further biotechnological application as hydrocarbon-degraders in bioremediation of oil-polluted soils. All the strains of lactic acid bacteria were able to form circle displacement area in engine oil $2 T$ with various diameters, confirming the production of biosurfactants in various amounts. Emulsification activity was registered, with values of emulsification index E24 ranging from minimum 25.75\% for the strain LAB 132 to maximum $75.93 \%$ for the strain LAB 13. Bacterial cells presented adhesion to hydrocarbons (kerosene), degrees of hydrophobicity variable, ranged between 25,57\% for LAB 58 and 75,42\% for Lpl and formed emulsions stable for over 7 days. Results of the assay of ionic charge revealed the anionic nature of the biosurfactants.
\end{abstract}

Keywords: biosurfactants, lactic acid bacteria, emulsification, hydrophobicity, cell adhesion to hydrocarbons.

Biosurfactants are compounds produced by various microorganisms and differ by their molecular weight, specific action and other physical-chemical properties [1]. In the category of biosurfactants are included microbial compounds with low molecular weight (lipopeptides, glycolipids) and high molecular weight (polysaccharides, lipopolysaccharides, lipoproteins, proteins). Their action is connected with reducing surface superficial tension at interface between two solutions and leads to stabilization of emulsions. The most studied biosurfactants are those produced by bacteria (genera Bacillus and Pseudomonas). When compared with synthetic surfactants, microbial biosurfactants present the advantage of diversity and biodegradability, that can determine certain specific functions, such as: the solubility of hydrophobic compounds, binding of heavy metals, antimicrobial and antiadhesive (antibiofilm) properties [2]. Recent studies revealed that various species of lactic acid bacteria were able to synthesize biosurfactants $[3,4,5]$. Increased interest for the study of biosurfactant producing lactobacilli is motivated by the utilization of these bacteria as probiotics [6], as well as for their ability to inhibit pathogenic bacteria and fungi [7]. Chemical nature of biosurfactants produced by lactobacilli was examined for different species: L.helveticus (glycolipids) [8]; L.pentosus, L.lactis, L.paracasei (glycoproteins or glyco-lipopeptides), L.plantarum (glycolipids or glycoproteins) [9,4]. Antimicrobial and antiadhesive action of biosurfactants produced by lactobacilli have been studied especially against a series of pathogenic bacteria and less against filamentous fungi. New perspectives due to their biodegradability are opened in environmental sector for bioremediation of contaminated soil or in waste treatment [10].

The objective of the present research was to evaluate the capacity of 10 lactic acid bacteria strains of various origins, with antifungal activity to produce biosurfactants and to select the most active strains for further practical application in bioremediation of soils polluted with oil hydrocarbons.

\section{Experimental part}

Lactic acid bacteria strains and culture media

Pure cultures of lactic acid bacteria representing 10 strains of various origins from the collections of National Research-Development Institute for Soil Science, Agrochemistry and Environment-ICPA, Bucharest (strain LCM5), Institute of Biology-IBB, Bucharest and UASVM, Faculty of Biotechnology (strains LAB 13, LAB 15, LAB 35, LAB43, LAB58, LAB 64 and reference strains Lpa and Lpl) have been assayed for the capacity to produce biosurfactants. Microbial strains were cultivated on liquid media MRS broth (purchased from Liofilchem Italy) in test tubes at $28 \pm 2^{\circ} \mathrm{C}$ for 24 or 48 hours [11]. The strains presented antifungal activity against food contaminants from genera Aspergillus and Penicillium [12, 13].

\footnotetext{
*email:so_matei602003@yahoo.com
} 


\section{Oil spreading assay}

Oil spreading assay was performed by the method of [2] to reveal the production of biosurfactants by the strains of lactic acid bacteria. A Petri dish of $100 \mathrm{~mm}$ diameter was filled with distilled water and a drop of engine oil $2 \mathrm{~T}$ (www.bervas.ro) was added to the surface of water. The oil formed a hydrophob film onto water surface. Then, $20 \mu \mathrm{l}$ from 48 hours cultures on MRS medium belonging to each of the 10 lactic acid bacteria strains were applied on the surface. The size of the resultant oil-displaced circle area was measured to reflect the surface activity of biosurfactant produced by each strain. Distilled water was used as negative control (Mt-) and a commercial detergent as positive control (Mt+). Each sample was repeated in triplicate. The results were interpreted by single-factorial analysis of variance. The value of $\mathrm{p}<0.05$ was considered statistically significant (Student test).

\section{Emulsification index and activity}

Emulsification activity of biosurfactants produced extracellularly by lactic acid bacteria strains was measured by calculating the Emulsification index $\left(\mathrm{E}_{24}\right)$ [14]. Kerosene was added to the supernatant of MRS culture broth of lactic acid bacteria strains $(1: 2 \mathrm{v} / \mathrm{v})$. The mixture was vigorously mixed for 2 minutes and left undisturbed for 24 hours. The high of the layer of stable emulsion was measured and the emulsification index $E_{24}$ was calculated as the percentage of the high of emulsion layer formed divided by the total high of the solution, using the formula:

$$
\mathrm{E}_{24}=\mathrm{h}_{\text {emulsion }} / \mathrm{h}_{\text {total }} \mathrm{x} 100 \%
$$

Emulsification capacity (E24 index) correlates with the concentration of biosurfactant produced by each lactic acid bacteria strain. The results were interpreted by single-factorial analysis of variance. The value of $p<0.05$ was regarded as statistically significant (Student test).

\section{Bacterial adhesion to hydrocarbons assay}

Microbial surface hydrophobicity was assessed by microbial adhesion to hydrocarbons assay. Adhesion of bacterial cells to hydrocarbons was tested by using the photometric method [15] based on the degree of adherence of bacterial cells to various liquid hydrocarbons. In order to measure this parameter, $1 \mathrm{ml}$ suspension of 24 hours liquid cultures of lactic acid bacteria in MRS broth was mixed vigorously with $5 \mathrm{ml}$ kerosene for 2 minutes and the two phases allowed to separate. Hydrophobic cells adhered to kerosene droplets and rose to the surface together with these. They were carefully removed from aqueous phase and the turbidity of aqueous phase was measured. Decreasing the turbidity of aqueous phase correlates to the hydrophobicity of the cells. The percent of cells linked to hydrophobic phase $(\mathrm{H})$ was calculated using formula:

$$
\mathrm{H}=1-\left(\mathrm{A}_{0} / \mathrm{A}_{1}\right) / \mathrm{A}_{0} \mathrm{x} 100,
$$

where $A_{0}$ is the absorbance of bacterial suspension without hydrophobic phase added and $A_{1}$ is the absorbance after mixing with hydrophobic phase. The capacity of bacteria to adhere to hydrocarbons is a characteristic feature of biosurfactant producing microorganisms. The results were interpreted by single-factorial analysis of variance. The value of $\mathrm{p}<0.05$ was regarded as statistically significant (Student test).

\section{Determination of ionic charge of biosurfactants}

The ionic properties of the biosurfactants produced by lactic acid bacteria strains with antifungal activity were determined by the agar well diffusion method [6]. Groups of three wells with the diameter of $8 \mathrm{~mm}$ were done at equal distances in Petri dishes with soft agar (1\%). The central well was filled with $100 \mu$ l biosurfactant produced by each bacteria strain. Each lateral well was filled with $100 \mu \mathrm{l}$ of anionic compound (sodium dodecyl-sulfate, $20 \mathrm{mM}$ ) and a cationic compound (dodecyl-dimethyl-ammonium chloride). Petri dishes were incubated at for 48 hours. The precipitation lines appeared indicated the ionic character of the biosurfactant produced [16].

\section{Results and discussions \\ Oil spreading}

The size of resultant oil-displaced circle area obtained by oil spreading assay reflects the surface activity of biosurfactant produced by lactic acid bacteria strains.

The aspect of Petri dishes where the displacement of engine oil $2 \mathrm{~T}$ was tested evidenced formation of clear circle areas of various diameters, that confirmed the possibility to produce biosurfactants for the majority of the bacterial strains (Fig.1). 


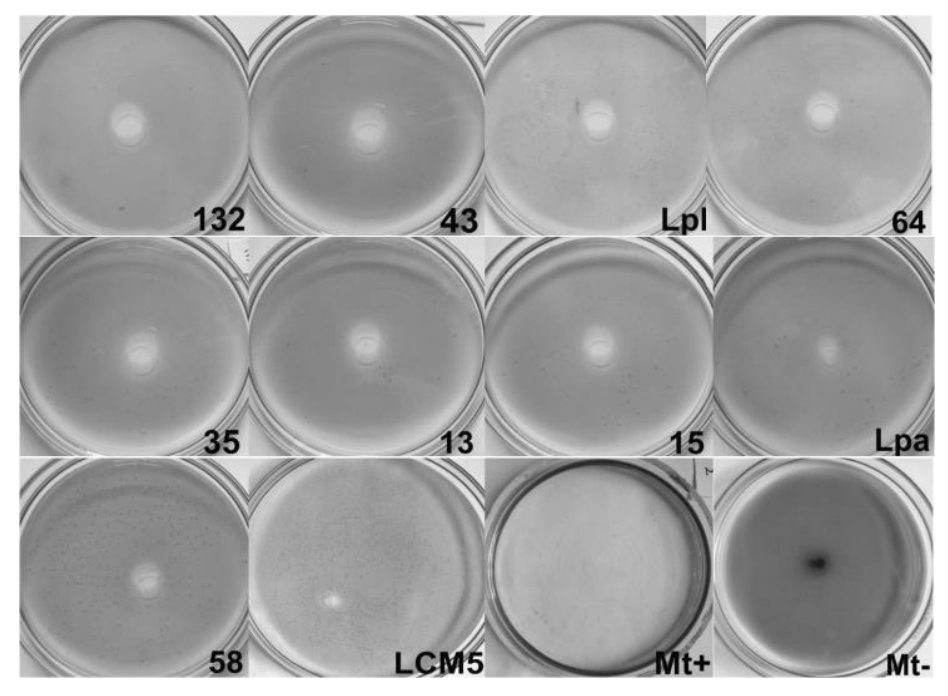

Fig.1. Clear displacement area of engine oil $2 \mathrm{~T}$ formed by the biosurfactants produced by lactic acid bacteria strains compared with commercial detergent $(\mathrm{Mt}+)$ and distilled water (Mt-)

The diameters of circle clear area ranged between $4 \mathrm{~mm}$ and $13 \mathrm{~mm}$, the highest quantities of biosurfactants able to disperse a large area of engine oil being produced by the strains LAB132, LAB 43, Lpl and LAB 64 (Fig.2).

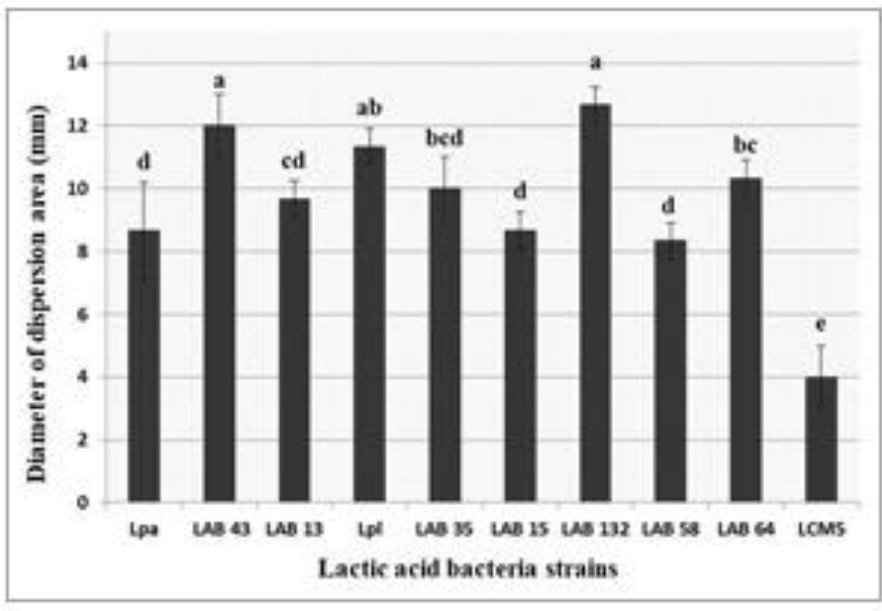

Values followed by the same letter are not significantly different for $\mathrm{p}<0.05$ (Student test).

Fig.2. Dispersion area diameters of engine oil

2T made by biosurfactants produced by lactic acid bacteria strains

The results of the assay are in concordance with literature data repporting formation of clear dispersion areas of variable diameters as a function of microbial species producing the biosurfactant or on the concentration of biosurfactant assayed $[17,18]$.

Similar results were also obtained for biosurfactants with antimicrobial and antiadhesive properties isolated from Lactobacillus paracasei ssp. paracasei A20 strain [3,19] and for 15 biosurfactant-producing strains of Lactobacillus with anti-biofilm effect on Candida albicans [1].

\section{Emulsification index and activity}

Supernatants of lactic acid bacterial strains were further tested for the emulsification capacity. Thus, the specific emulsification activity of biosurfactants produced by the ten strains of lactic acid bacteria was expressed as values of emulsification index E24 (Fig.3).

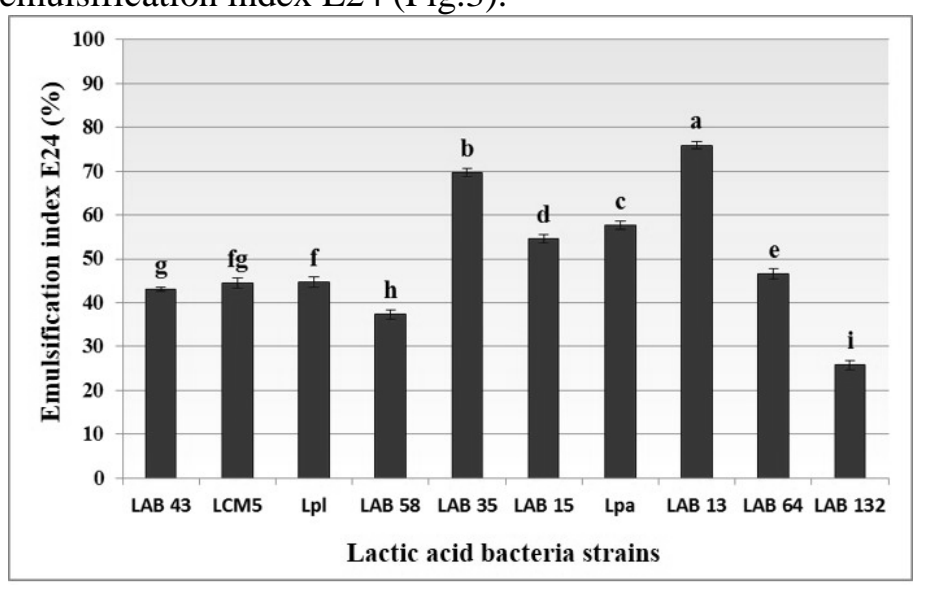

Values followed by the same letter are not significantly different for $\mathrm{p}<0.05$ (Student test).

Fig.3. Emulsification capacity (E24 index) of biosurfactants produced by lactic acid bacteria strains 
Values of emulsification index E24 ranged from minimum $25.75 \%$ for the strain LAB 132 to maximum $75.93 \%$ for the strain LAB 13. Values higher than 50\% of E24 index were calculated for the strains LAB 35, Lpa and LAB 15. Biosurfactants produced by the strains LAB 64, Lpl, LCM5 and LAB 43 presented similar emulsification capacities, with values of E24 index between $40 \%$ and $50 \%$ and lower values of $37.33 \%$ for the strain LAB 58. Results of the study of emulsification capacity of biosurfactants produced by lactic acid bacteria strains are in concordance with literature [20] citing values of $45 \%$ to $72 \%$ of E24 index for biosurfactans syntesized by Lactobacillus strains isolated from various species of fresh water fishes, as a function of the nature of hydrocarbons utilized (diesel oil, toluene, gasoline, kerosene, hexane). Other researchers [17] repported E24 values of 7.8\%-63.3\% for biosurfactants produced by microorganisms isolated from oil polluted soils and that emulsion stability maintained more than one week. The aspect of kerosene emulsion formed by the ten strains of lactic acid bacteria in our assay was also maintained over 7 days (Fig.4). Different droplets size are visible, the droplets size being inversely proportional with emulsifying activity.

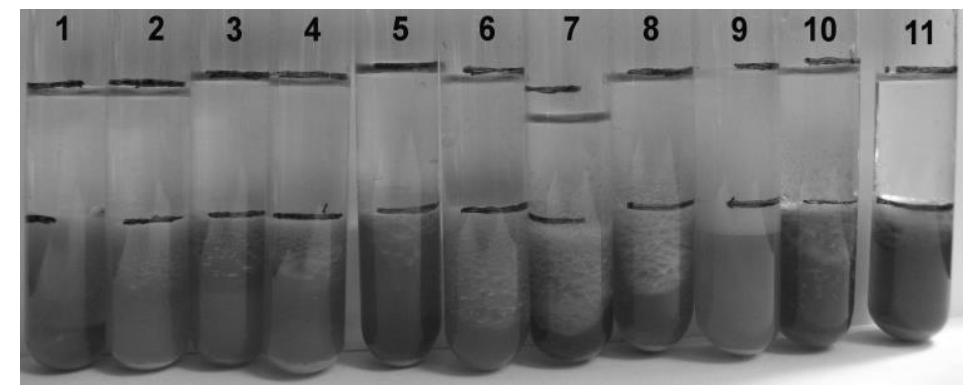

Fig.4. The appearance of emulsions formed by lactic acid bacteria strains:

1-Control-MRS, 2-LAB 43, 3-LCM5, 4-Lpl, 5-LAB

58, 6-LAB 35, 7-LAB 15, 8-Lpa,

9-LAB 13, 10-LAB 64, 11-LAB 132

\section{Bacterial adhesion to hydrocarbons}

Bacterial suspensions have been assayed for adhesion of cells to hydrocarbons (kerosene) and differences of adhesion reflected differences in microbial surface hydrophobicity (Fig.5).

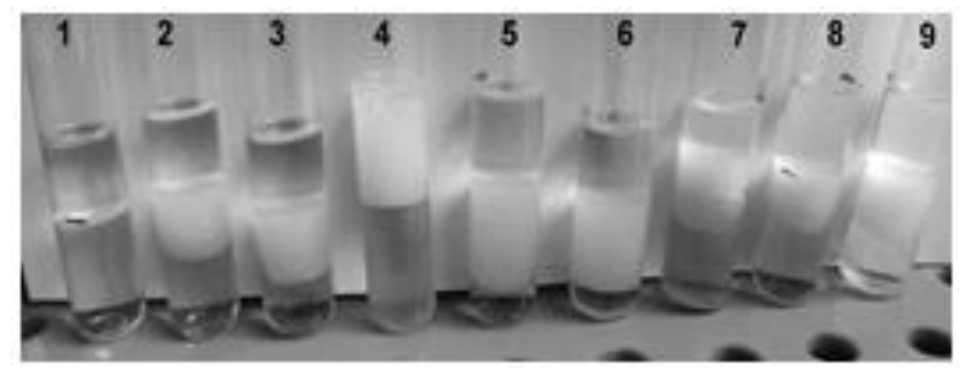

Fig.5. Lactic acid bacteria adhesion to hydrocarbons:

1- Control, 2-LAB 43, 3-LCM5, 4-Lpl, 5-LAB 58, 6-LAB 35, 7-LAB 15, 8-Lpa, 9-LAB 13

According to literature, there is a direct connection between surface cell hydrophobicity and the biosurfactant production. Generally, bacteria that uptake the hydrocarbons directly show high surface hydrophobicity and produce cell bound biosurfactants but the lower surface hydrophobicity of other microorganisms is due to extracellularly released biosurfactants [21]. The results obtained from our experiment revealed percent cells bound to hydrophobe phase ranging between $25,57 \%$ for LAB 58 and 75,42\% for Lpl (Fig.6).

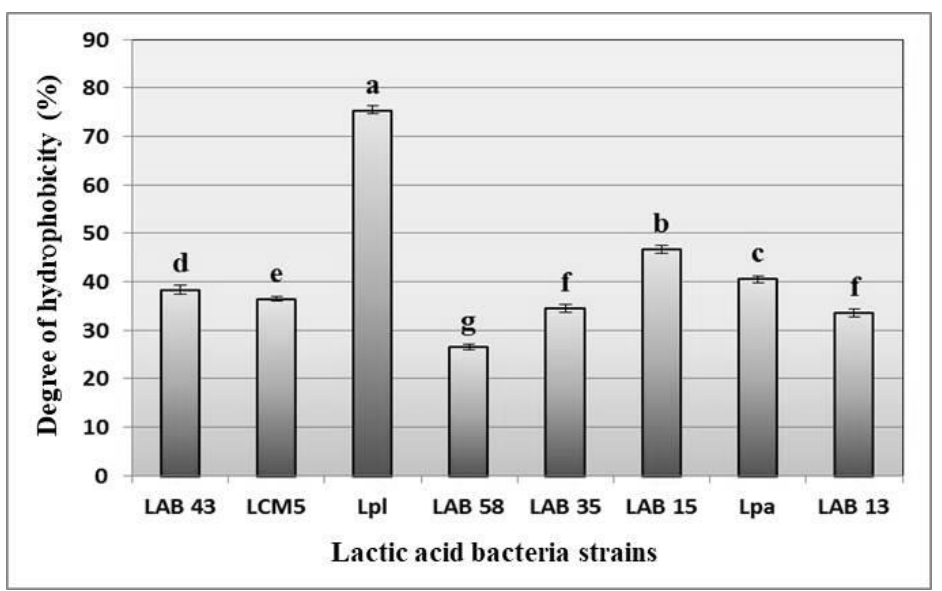

Values followed by the same letter are not significantly different for $\mathrm{p}<0.05$ (Student test). Fig.6. Hydrophobicity of lactic acid bacteria strains 
As compared to these results from lactic acid bacteria, significantly higher hydrophobicity were found for two Candida species than for Pseudomonas aeruginosa, using adhesion to hydrocarbon (diesel oil) assay, with values rangig from $59,40 \%$ to $92,76 \%$ [18]. Other research on biosurfactants prooduced by yeasts revealed emulsification activity, stability and cell adhesion to petroleum and alkanes for various strains isolated from oil-polluted soil, able to assimilate the hydrocarbons into their cells [22]. Proliferating lipid bodies into the cells indicated correlation between biosurfactant and utilization of hydrocarbon for lipid synthesis [23].

\section{The ionic charge of biosurfactants}

Assessment of ionic charge of biosurfactants carried out by agar well diffusion method based on passive diffusion of two compounds bearing similar or opposite ionic charge into a gel with low concentration. This test revealed precipitation lines between biosurfactants produced by the strains of lactic acid bacteria and the selected compound with cationic character (dodecyl-dimethyl-ammonium chloride) but no precipitation lines were registered between biosurfactant produced by each of the ten strains and anionic compound (sodium dodecyl-sulfate) (Fig.7).

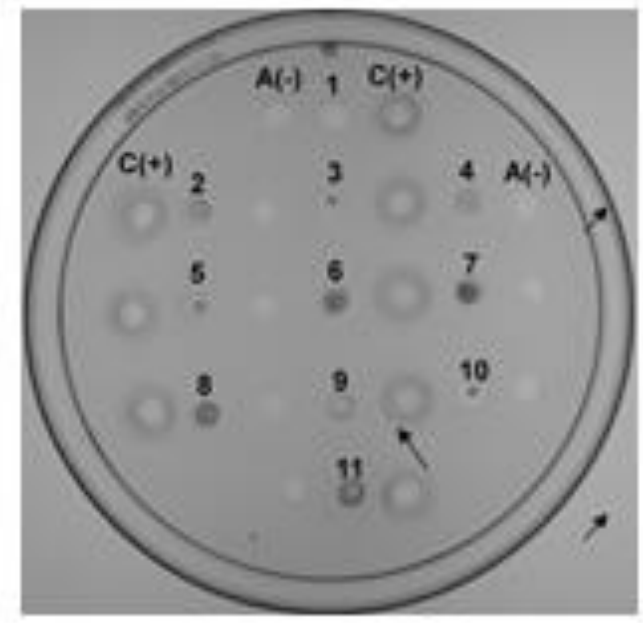

Fig.7. Anionic character of biosurfactants produced by lactic acid bacteria: 1-Control-MRS, 2-LAB 43, 3-LCM5, 4-Lpl, 5-LAB 58, 6-LAB 35, 7-LAB 15, 8-Lpa, 9-LAB 13, 10-LAB 64, 11-LAB 132; $\mathrm{C}(+)=$ dodecyl-dimethyl-ammonium chloride and $\mathrm{A}(-)=$ sodium dodecyl-sulfate.

Arrows indicate the precipitation lines between interacting solutions

Results indicated the anionic character of biosurfactants produced by lactic acid bacteria strains. Similar results revealing the anionic character of biosurfactants produced by lactic acid bacteria were obtained for species such as: Enterococcus faecium, isolated from butter milk [6], Lactococcus lactis [24], but also for Gram negative bacteria Pseudomonas fluorescens [16]. Tests utilized for the screening of lactic acid bacteria for production of biosurfactants and their characterization are considered in literature as rapid and very efficient. are Thus, oil spreading was appreciated as rapid and very efficient (++), the emulsification capacity and adhesion of bacteria to hydrocarbons as rapid and efficient $(+)$, these assays proving their implication in selection of efficient lactic acid bacteria strains producing biosurfactants with antimicrobial role [25].

\section{Conclusions}

All the strains of lactic acid bacteria were able to form circle displacement area in engine oil $2 \mathrm{~T}$ with various diameters, confirming the production of biosurfactants in various amounts, with anionic character. The capacity of biosurfactants produced by lactic acid bacteria strains to adhere to hydrocarbons may be another reason for their utilization in further environmental friendly biotechnologies using effective methods for bioremediation of soils polluted with oil hydrocarbon residues. Correlating the results relating to the biosurfactants with those concerning the antifungal activity, it can be appreciated that, at least for LAB 13, LAB 35 and LAB 43 strains, these properties are related to the production of biosurfactants. Further research are needed for characterization of purified biosurfactants and optimization of growth conditions of lactic acid bacteria strains for obtaining efficient biosurfactants with complex properties, including antimicrobial action and degradation of oil hydrocarbons.

Acknowledgments: The results were obtained under the frame of European Social Fund, Human Resources Development Operational Programme 2007-2013, project no. POSDRU/159/1.5/S/132765 and of the Romanian National Authority for Scientific Research, CNDIUEFISCDI, project number PN-III-P2-2.1_PTE-2016-0084, (40-PTE), ECOREMTEH.

\section{References}

1.FRACCHIA, L., CAVAllo, M., AllegRONE, G., MARTINOTTI, M.G., In: Current Research Technology and Education Topics in Applied Microbiology and Microbial Biotechnology, Mendez-Vilas A., (ed), Formatex Research center, Extremadura, Spania, 2010

2.RODRIGUES, L., BANAT, I.M., TEIXEIRA, J., OLIVEIRA, R., J. Antimicrob. Chemother., 57, nr. 4, 2006, p. 609

3.GUDINA, E.J, ROCHA, V., TEIXEIRA, J.A, RODRIGUES, L.R., Lett. Appl. Microbiol., 50, 2010, p. 419

4.MADHURI, K.V., PRABHAKAR, K.V., Oriental J.Chem., 30, 2014. available online at: http://www.orientjchem.org/ pdf/vol30no2/ OJCV030I02P895-904.pdf 
5.SAMBANTHAMOORTHY, K., FENG, X., PATEL, R., PATEL, S., PARANAVITANA, C., BMC Microbiol., 14, 2014. available online at: http://www.biomedcentral.com/content/pdf/1471-2180-14-197.pdf

6.SHARMA, D., SAHARAN, B.S., CHAUHAN, N., PROCHA, S., LAL, S., SpringerPlus 4, 2015, p. 4, available online at: http://www. springerplus.com/content/4/1/4

7.CORNEA, C.P., SICUIA, O.A., POPA, G., ISRAEL, F., ZAMFIR, M., 2013, available online at: http://www.sciencedirect. com/science/ article/pii/S0958166913003868

8.SHARMA, D., SINGH, B.S., Int. J. Microbiology, 2014, available online at: http://downloads.hindawi. com/ journals/tswj/2014/493548.pdf

9.SAUVAGEAU, J., RYAN, J., LAGUTIN, K., SIMS, I.M., STOCKER, B.L., TIMMER, M.S., Carbohydrate Res., 357, 2012 , p. 151

10.PADMAPRIYA, B., SUGANTHI, S., ANISHYA, R., 2013. American-Eurasian J. Agric. \& Environ. Sci., 13, nr. 2 , p. 227

11.DE MAN, J.C., ROGOSA, M., SHARPE, M.E., J. Appl. Bacteriol., 23, 1960, p. 130

12.MATEI, A., CORNEA, C.P., MATEI, G.M., J. Biotechnol., available online at: http://dx.doi.org/10.1016/j. jbiotec.2015.06.243

13.MATEI, A., CORNEA, C.P., MATEI, S., MATEI, G.M., RODINO, S., Bul. UASVM Food Sci. Technol., 72, nr. 2, 2015 , p. 226

14.COOPER, D., GOLDENBERG, B., Appl. Environ. Microbiol., 53, nr. 2, 1987, p. 224

15.ROSENBERG, M., GUTNICK, D., ROSENBERG, E., FEMS Microbiol. Lett., 9, nr.1, 1980, p. 29

16.MEYLHEUC, T., VAN OSS, C.J., BELLON-FONTAINE, M. N., J. Appl. Microbiol., 91, nr. 5, 2001, p. 822

17.TECHAOEI, S., LEELAPORNPISID, P., SANTIARWARN, D., LUMYONG, S., KMITL Sci. Technol. J., 7, 2007, p. 38

18.PADMAPRIYA, B., SUGANTHI, S., 2013. Middle-East J. Sci. Res., 14, nr. 10, p. 1359

19.GUDINA, E.J., TEIXEIRA, J.A., RODRIGUES, L.R., Appl. Environ. Soil Sci., 2011, available online at: http://www. hindawi. com/journals/aess/2011/201254/

20.SANKAR, S., SENTHIL BALAN, S., JAYALAKSHMI, S., Internat. J. Current Trends in Res., 2, nr. 1, 2013, p. 338

21.SATPUTE, S.K., BANPURKAR, A.G., DHAKEPHALKAR, P.K., BANAT, I., CHOPADE, B.A., Crit. Rev. Biotechnol., 32, nr. 2, 2010, p. 127

22.CSUTAK, O., STOICA, I., VASSU, T., Rev. Chim. (Bucharest), 43, no.10, 2012, p. 973

23.CSUTAK, O., CORBU, V., VASSU, T., Rev. Chim. (Bucharest), 68, no.2, 2017, p. 255

24.SARAVANAKUMARI, P., MANI, K., Biores. Technol., 101, nr. 22, 2010, p. 8851

25.WALTER, V., SYLDATK, C., HAUSMANN, R., In Biosurfactants, Springer New York, 2010, p. 1

$\overline{\text { Manuscript received: } 17.09 .2018}$ 